\title{
Genotypic variation in spatiotemporal distribution of canopy light interception in relation to yield formation in cotton
}

\author{
XING Fangfang ${ }^{1,2}$, HAN Yingchun 1,2, FENG Lu ${ }^{1,2}$, ZHI Xiaoyu ${ }^{1,2}$, WANG Guoping ${ }^{1,2}$, YANG Beifang ${ }^{1,2}$, FAN Zhengyi ${ }^{1,2}$,
} LEI Yaping ${ }^{1,2}$, DU Wenli ${ }^{1,2}$, WANG Zhanbiao ${ }^{1,2}$, XIONG Shiwu $^{1,2}$, LI Xiaofei $^{1,2}$ and LI Yabing ${ }^{1,2^{*}}$

\begin{abstract}
Background: Within-canopy interception of photosynthetically active radiation (PAR) impacts yield and other agronomic traits in cotton (Gossypium hirsutum L.). Field experiments were conducted to investigate the influence of 6 cotton varieties (they belong to 3 different plant types) on yield, yield distribution, light interception (LI), LI distribution and the relationship between yield formation and LI in Anyang, Henan, in 2014 and 2015.

Result: The results showed that cotton cultivars with long branches (loose-type) intercepted more LI than did cultivars with short branches (compact-type), due to increased LI in the middle and upper canopy. Although loose-type varieties had greater $\mathrm{LI}$, they did not yield significantly higher than compact-type varieties, due to decreased harvest index. Therefore, improving the harvest index by adjusting the source-to-sink relationship may further increase cotton yield for loose-type cotton. In addition, there was a positive relationship between reproductive organ biomass accumulation and canopy-accumulated $\mathrm{LI}$, indicating that enhancing $\mathrm{LI}$ is important for yield improvement for each cultivar. Furthermore, yield distribution within the canopy was significantly linearly related to vertical LI distribution.
\end{abstract}

Conclusion: Therefore, optimizing canopy structure of different plant type and subsequently optimizing LI distribution within the cotton canopy can effectively enhance the yield.

Keywords: Cotton cultivars, Light interception, Plant type structure, Boll distribution, Yield

\section{Background}

The capacity of the crop canopy to intercept and efficiently use solar radiation can greatly influence crop growth and development. Photosynthetically active radiation (PAR), consisting of wavelengths that can be absorbed by green plants and used for photosynthesis (Madakadze et al. 1998; Maddonni and Otegui 1996; McIntyre et al. 1996), is the major driver of plant photosynthetic processes(Meir et al. 2002). Spatial canopy interception determines how much PAR reaches the elements of the canopy and helps to determine the optimal canopy form for a certain crop. Light interception (LI) by the canopy is an important environmental factor, in addition to

\footnotetext{
* Correspondence: criliyabing1@163.com

${ }^{1}$ Zhengzhou Research Base, State Key Laboratory of Cotton Biology,

Zhengzhou University, Zhengzhou 450000, Henan, China

${ }^{2}$ Institute of Cotton Research of Chinese Academy of Agricultural Sciences,

Anyang 455000, Henan, China
}

genetic factors (Bai et al. 2016), that determines the plant architecture type (Xue et al. 2015).

Knowing the factors that affect and determine yield and the ability to predict the yield of crops through in-season measurements are of paramount importance. Crop yield is highly correlated with canopy light interception, leaf area index (LAI) and above ground biomass in vegetables, soybeans, maize, sorghum, cotton and rice (Mo et al. 2005; Zarate-Valdez et al. 2012). The amount of light intercepted by the canopy and Radiation Use Efficiency (RUE) hich is the efficiency of converting the captured radiinto biomass, are crucial elements for crop production and development (Louarn et al. 2008). LI is termined by canopy configuration (Chen et al. 1997; Dauzat et al. 2008), which increases not only land productivity but also resource use efficiency. Some studies have indicated that leaf area components have the greatest effect on light intensities (Baldissera et al. 2014). Among 
the characteristics that increase economic yield, the canopy microclimate is considered very important. PAR interception can be altered by canopy construction (Barthélémy and Caraglio 2007) and leaf area (Vargas et al. 2002). Therefore, in-depth exploration of the precise characteristics of light distribution in a crop canopy is necessary for improving crop productivity.

In cotton (Gossypium hirsutum L), adequate LI is essential for growth. Understanding the effects of plant architecture on radiation interception by cotton can be very useful for optimizing canopy architecture to intercept more light. The goal of cotton agronomy is to improve cotton yields through optimal management, but this accomplishment is made more difficult by the perennial growth habit of cotton (Kaggwa-Asiimwe et al. 2013). In addition, there is limited knowledge on how sink-source relationships and biomass production are affected by light interception(Wang et al. 2016) and how these relationships may be manipulated by different cultivars. The optimal spatial distribution of light and the specific boll spatial distribution are important for the efficient utilization of light. Therefore, identifying and selecting optimal cotton cultivars with a high efficiency for intercepting and converting solar radiation, as well as better understanding the characteristics of radiation interception and dry matter accumulation in more detail, are crucial.

Few studies have compared spatial LI and biomass production in different cultivars, and LI in different vertical and horizontal zones of the canopy has not yet been determined. In this study, the primary objective was to determine how different cotton cultivars alter the canopy LI in different vertical and horizontal zones of the canopy, the boll spatial distribution and the seed cotton yield. A secondary objective was to evaluate how the boll spatial distribution, biomass, LAI and seed cotton yield were altered by LI variation.

\section{Results}

Yield and yield components of different cultivars

In this study, yield and yield components were significantly different among different cultivars (Table 1). The seed cotton yields of different varieties ranged from 4164 to $4.672 \mathrm{~kg} \cdot \mathrm{hm}^{-2}$ and from 4129 to $4616 \mathrm{~kg} \cdot \mathrm{hm}^{-2}$ in 2014 and 2015, respectively. J958 and L28 had a higher yield than did C915, C113 and C60 but a yield similar to that of J228 in 2014. In 2015, J228 had the greatest yield, $4616 \mathrm{~kg} \cdot \mathrm{hm}^{-2}$, while C915 had the lowest yield, $4129 \mathrm{~kg} \cdot \mathrm{hm}^{-2}$. Regarding the yield components, no significant difference was observed in boll number per plant in 2014, but in 2015, C113 and L28 had more bolls per plant than did J228 and J958. J228 and J958 had the greatest boll weight, while $\mathrm{C} 60$ and $\mathrm{C} 113$ had the lowest boll weight among all cotton varieties in both years. No obvious difference in cotton yield between plant types was observed. However, the compact-type cultivar L28 had relatively more bolls per plant (10.6 bolls.plant ${ }^{-1}$ in 2014 and 10.9 bolls.plant ${ }^{-1}$ in 2015), while the loose-type varieties J958 and J228 had relatively heavier bolls (6.7 and $6.3 \mathrm{~g}^{\mathrm{boll}}{ }^{-1}$ in 2014, 6.7 and $6.9 \mathrm{~g} \cdot \mathrm{boll}^{-1}$ in 2015).

\section{The spatial yield distribution within canopy of different cultivars}

The spatial yield distribution was significantly different both vertically and horizontally among cotton varieties and plant types (Table 2). L28 and C915 had higher yield (29.4\% and 27.9\%) while J958 had lower yield (18.0\%) distributed in the upper canopy in 2014. In 2015, similar trends were also observed, with L28, C915 and C60 having more yield (28.0\%, 27.5\% and 26.7\%) and J958 having less yield $(22.5 \%)$ distributed in the upper canopy. In the middle canopy, J228 had the greatest yield distribution in both years (53.9\% in 2014 and $55.1 \%$ in 2015). In contrast, C915 and L28 had the least yield distribution in the middle canopy in both years. In the lower canopy, C915 possessed the greatest yield distribution, while J228 possessed the lowest yield distribution in both years. It is interesting that loose-type cultivars had more yield distributed in the middle canopy, while compact-type cultivars had more yield distributed in the upper and lower canopy.

Horizontally, C915 had more yield (99.1\%) distributed in the inner part of the plant than did other varieties,

Table 1 Varietal effects on cotton yield and yield components in 2014 and 2015

\begin{tabular}{|c|c|c|c|c|c|c|c|}
\hline \multirow[t]{2}{*}{ Cultivar } & \multirow[t]{2}{*}{ Structure } & \multicolumn{2}{|c|}{ Seed cotton yield $/\left(\mathrm{kg} \cdot \mathrm{hm}^{-2}\right)$} & \multicolumn{2}{|c|}{ Boll number per plant } & \multicolumn{2}{|c|}{ Boll weight /g } \\
\hline & & 2014 & 2015 & 2014 & 2015 & 2014 & 2015 \\
\hline L28 & Compact & 4616 a§ & $4494 a b$ & 10.6 & 10.9 a & $6.0 \mathrm{~b}$ & $6.1 \mathrm{~b}$ \\
\hline C915 & Compact & $4164 c$ & $4129 d$ & 9.9 & $10.1 \mathrm{ab}$ & $5.8 \mathrm{bc}$ & $5.9 \mathrm{bc}$ \\
\hline C113 & Medium & $4308 c$ & $4353 \mathrm{abc}$ & 10.2 & 10.9 a & $5.4 \mathrm{c}$ & $5.9 \mathrm{bc}$ \\
\hline $\mathrm{C} 60$ & Medium & $4350 \mathrm{bc}$ & $4208 \mathrm{~cd}$ & 10.3 & $10.4 \mathrm{ab}$ & $5.4 \mathrm{c}$ & $5.8 \mathrm{c}$ \\
\hline$J 228$ & Loose & $4543 a b$ & $4616 a$ & 9.9 & $8.9 \mathrm{~b}$ & $6.7 \mathrm{a}$ & $6.7 \mathrm{a}$ \\
\hline J958 & Loose & $4672 a$ & $4427 \mathrm{ab}$ & 9.7 & $8.8 \mathrm{~b}$ & $6.3 a b$ & 6.9 a \\
\hline LSD & & 294 & 216 & NS & 1.7 & 0.5 & 0.3 \\
\hline
\end{tabular}

$\S$ Similar lower case letters indicate no significant difference among cotton varieties at the $P=0.05$ level 
Table 2 Spatial yield distribution within the cotton canopies of different cultivars in 2014 and 2015

\begin{tabular}{|c|c|c|c|c|c|c|c|c|}
\hline \multirow[t]{2}{*}{ Cultivar } & \multicolumn{2}{|c|}{$\begin{array}{l}\text { Upper } \\
1 \%\end{array}$} & \multicolumn{2}{|c|}{$\begin{array}{l}\text { Middle } \\
1 \%\end{array}$} & \multicolumn{2}{|c|}{$\begin{array}{l}\text { Lower } \\
1 \%\end{array}$} & \multicolumn{2}{|l|}{$\begin{array}{c}\text { Inner } \\
1 \%\end{array}$} \\
\hline & 2014 & 2015 & 2014 & 2015 & 2014 & 2015 & 2014 & 2015 \\
\hline C915 & $\begin{array}{l}27.9 \\
a \S\end{array}$ & $\begin{array}{l}27.5 \\
a b\end{array}$ & $\begin{array}{l}37.5 \\
c\end{array}$ & $\begin{array}{l}40.2 \\
c\end{array}$ & $\begin{array}{l}34.6 \\
a\end{array}$ & $\begin{array}{l}32.3 \\
a\end{array}$ & $\begin{array}{l}99.1 \\
a\end{array}$ & $\begin{array}{l}96.1 \\
a\end{array}$ \\
\hline L28 & $\begin{array}{l}29.4 \\
a\end{array}$ & $\begin{array}{l}28.0 \\
a\end{array}$ & $\begin{array}{l}40.3 \\
C\end{array}$ & $\begin{array}{l}42.0 \\
C\end{array}$ & $\begin{array}{l}30.3 \\
b\end{array}$ & $\begin{array}{l}29.9 \\
a b\end{array}$ & $\begin{array}{l}95.2 \\
a b\end{array}$ & $\begin{array}{l}95.1 \\
a\end{array}$ \\
\hline C60 & $\begin{array}{l}22.4 \\
b c\end{array}$ & $\begin{array}{l}26.7 \\
a b\end{array}$ & $\begin{array}{l}48.4 \\
b\end{array}$ & $\begin{array}{l}44.1 \\
C\end{array}$ & $\begin{array}{l}29.2 \\
b\end{array}$ & $\begin{array}{l}29.1 \\
b\end{array}$ & $\begin{array}{l}89.1 \\
\mathrm{~cd}\end{array}$ & $\begin{array}{l}87.7 \\
b\end{array}$ \\
\hline C113 & $\begin{array}{l}21.0 \\
c\end{array}$ & $\begin{array}{l}25.8 \\
a b\end{array}$ & $\begin{array}{l}49.0 \\
b\end{array}$ & $\begin{array}{l}45.5 \\
b c\end{array}$ & $\begin{array}{l}30.0 \\
b\end{array}$ & $\begin{array}{l}28.8 \\
b\end{array}$ & $\begin{array}{l}86.0 \\
d\end{array}$ & $\begin{array}{l}93.0 \\
a\end{array}$ \\
\hline J958 & $\begin{array}{l}18.0 \\
d\end{array}$ & $\begin{array}{l}22.5 \\
c\end{array}$ & $\begin{array}{l}50.2 \\
a b\end{array}$ & $\begin{array}{l}48.8 \\
b\end{array}$ & $\begin{array}{l}31.8 \\
b\end{array}$ & $\begin{array}{l}28.7 \\
b\end{array}$ & $\begin{array}{l}90.9 \\
\text { bcd }\end{array}$ & $\begin{array}{l}92.5 \\
a\end{array}$ \\
\hline $\mathrm{J} 228$ & $\begin{array}{l}23.8 \\
b\end{array}$ & $\begin{array}{l}25.1 \\
b\end{array}$ & $\begin{array}{l}53.9 \\
a\end{array}$ & $\begin{array}{l}55.1 \\
a\end{array}$ & $\begin{array}{l}22.3 \\
c\end{array}$ & $\begin{array}{l}19.9 \\
c\end{array}$ & $\begin{array}{l}92.3 \\
b c\end{array}$ & $\begin{array}{l}94.0 \\
a\end{array}$ \\
\hline LSD & 2.3 & 2.5 & 3.9 & 4.2 & 2.7 & 2.5 & 4.8 & 4.4 \\
\hline
\end{tabular}

$\S$ Similar lower case letters indicate no significant difference among cotton varieties at the $P=0.05$ level

except for L28 (95.2\%) in 2014, and C113 had the least yield in the inner part of the plant (86.0\%) (Table 2). In 2015, C60 had the least yield (87.7\%) distributed in inner part of the plant, but other varieties did not show any significant difference in the yield distribution of the inner part of the plant. Therefore, cotton varieties with compact plant type showed relatively more yield distribution in the inner part of the plant only in 2014.

\section{LI spatial distribution in canopies of different cultivars}

To study the LI spatial distribution, the values of the LI were calculated using the trapezoidal rule. There was a quadratic relationship between the LI of different cotton varieties and days after sowing. The canopy LI was significantly influenced by cotton cultivar and plant type (Fig. 1). No varietal differences were shown at earlier stages of growth, but varietal differences occurred from 60 days after sowing in 2014 and 80 days after sowing in 2015. LI of different cotton varieties peaked at the flowering and boll-setting stages in 2014 (90-100 d after sowing) and 2015 (100-110 d after sowing) and declined thereafter. LI peak values ranged from 0.49 to 0.68 . The accumulated LI of compact-type varieties was lower than that of loose-type cotton cultivars. The LI peak value of 5958 was the highest among that of all cultivars.

To further study the LI spatial distribution within canopy, the LI of different cultivars was divided into three equal parts in horizontal and vertical levels as shown in Fig. 2. These levels were designated $\mathrm{H}-1, \mathrm{H}-2, \mathrm{H}-3, \mathrm{~V}-1$, $\mathrm{V}-2$ and V-3 from bottom to top and left to right. LI had a quadratic relationship with days after sowing in both horizontal and vertical zones (Figs. 3, 4). Vertically, due to different canopy structures, loose-type cultivars intercepted more light than did compact-type cultivars in all zones except for H1. Similar to the canopy, varietal differences in LI occurred from the squaring stage (60-80 d) and peaked in the flowering and boll-setting stages (90-120 d). In 2014, the compact-type cultivars L28 and C915 had less LI in H1 than did the loose-type varieties J958 and J228. However, in 2015, the opposite result occurred in that L28 and C915 had more LI than did 5958 in $\mathrm{H} 1$ (Fig. 3). Regarding the different vertical parts within the canopy, the LI was highest in $\mathrm{H} 2$, followed by $\mathrm{H} 3$ and then $\mathrm{H} 1$ in both years. The LI values ranged from 0.01 to $0.18,0.06$ to 0.28 , and 0.01 to 0.27 , for $\mathrm{H} 1$, $\mathrm{H} 2$ and $\mathrm{H} 3$, respectively. In horizontal zones (Fig. 4), loose-type cultivars intercepted more LI than did compact cultivars in V2 in both years. The greatest varietal difference in LI in V2 occurred at 90-100 d after sowing in 2014 and at 90-120 d after sowing in 2015. In 2015, loose-type cultivars also intercepted more PAR than did

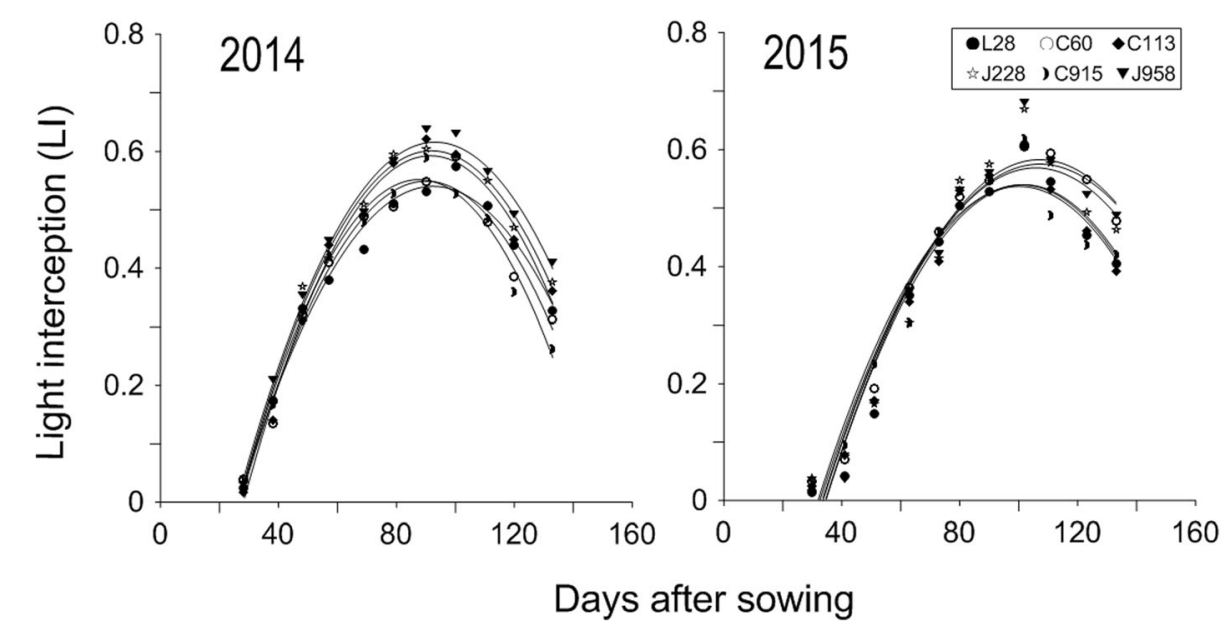

Fig. $1 \mathrm{LI}$ of six different cotton cultivars with different plant types during the cotton growth periods in 2014 and 2015 

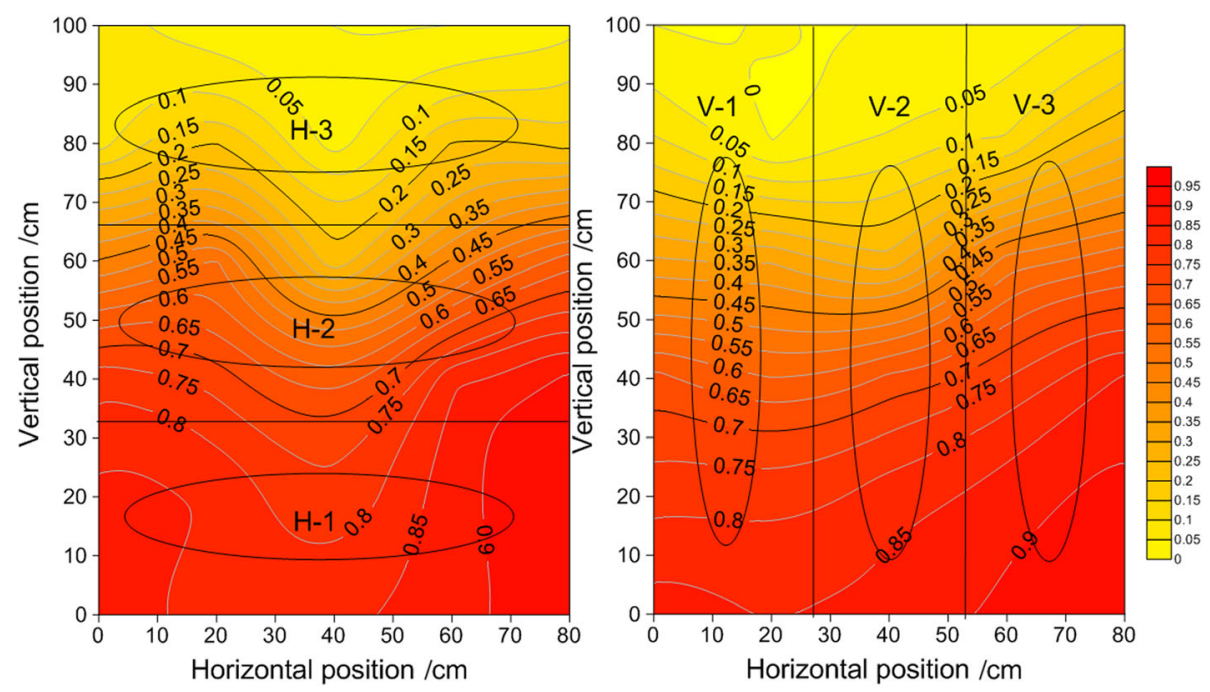

Fig. 2 LI spatial distribution of C915 and J228 in 2014

compact cultivars in V1 and V3, which did not occur in 2014. Among the three horizontal parts, V3 had the greatest LI, followed by V1, and V2 had the lowest LI. The LI ranged from 0.01 to $0.64,0$ to 0.59 , and 0.01 to 0.66 , for V1, V2 and V3, respectively.

\section{LAI and accumulated biomass}

Due to the different cotton planting types, LAI varied among cotton cultivars (Fig. 5). The peak values of LAI occurred later in 2015 than 2014. Varietal differences were small at the earlier stages of growth and then increased. LAI peak values ranged from 2.7 to 3.6. The LAI peak value of J228 was 3.58 in 2014 and 3.24 in 2015, the highest among all cultivars. C915 had the minimum LAI peak values (2.7 in both years). In addition, compact-type cultivars tended to have a lower LAI.

Two major determinants of high productivity in a cotton cultivar were its ability to produce high levels of assimilates by photosynthesis and to partition a

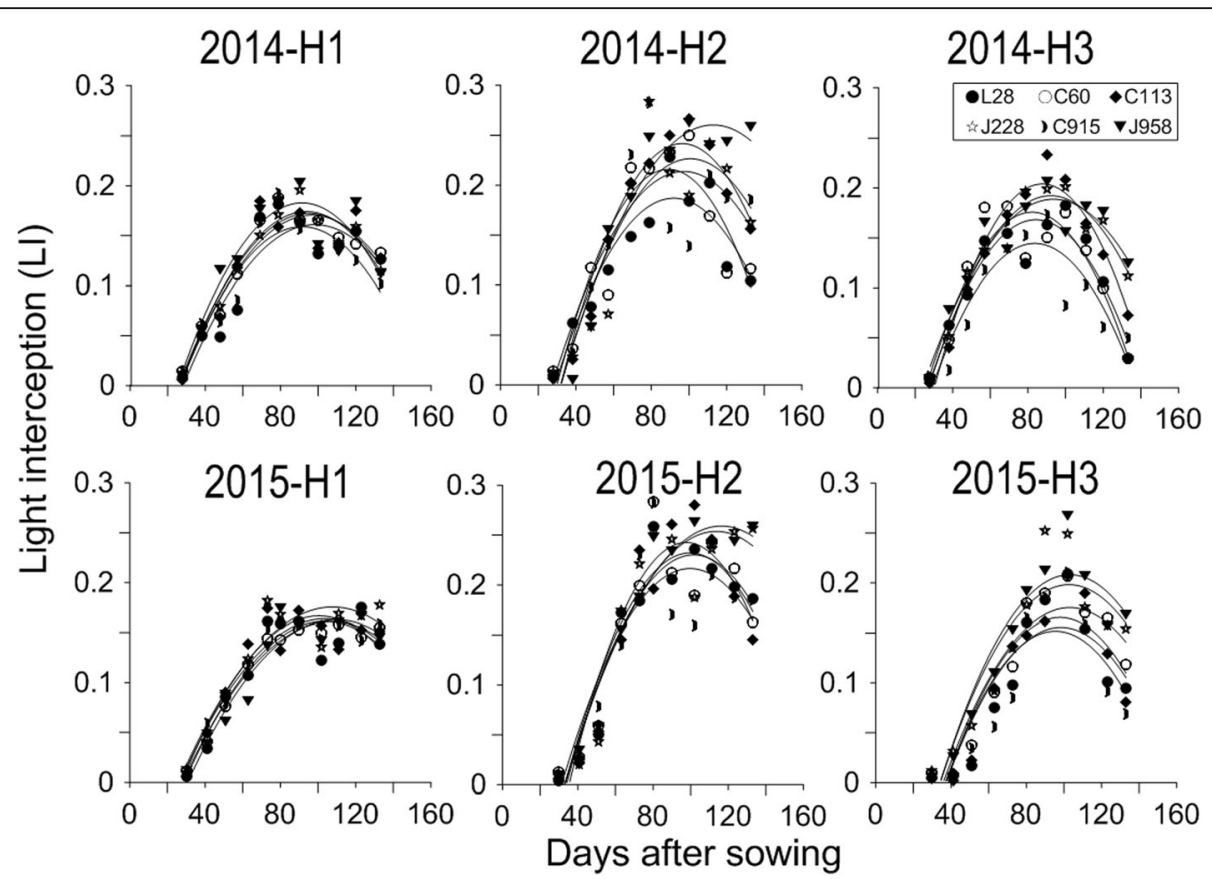

Fig. $3 \mathrm{LI}$ vertical distribution of six different cotton varieties with different plant types during the cotton growth period in 2014 and 2015 


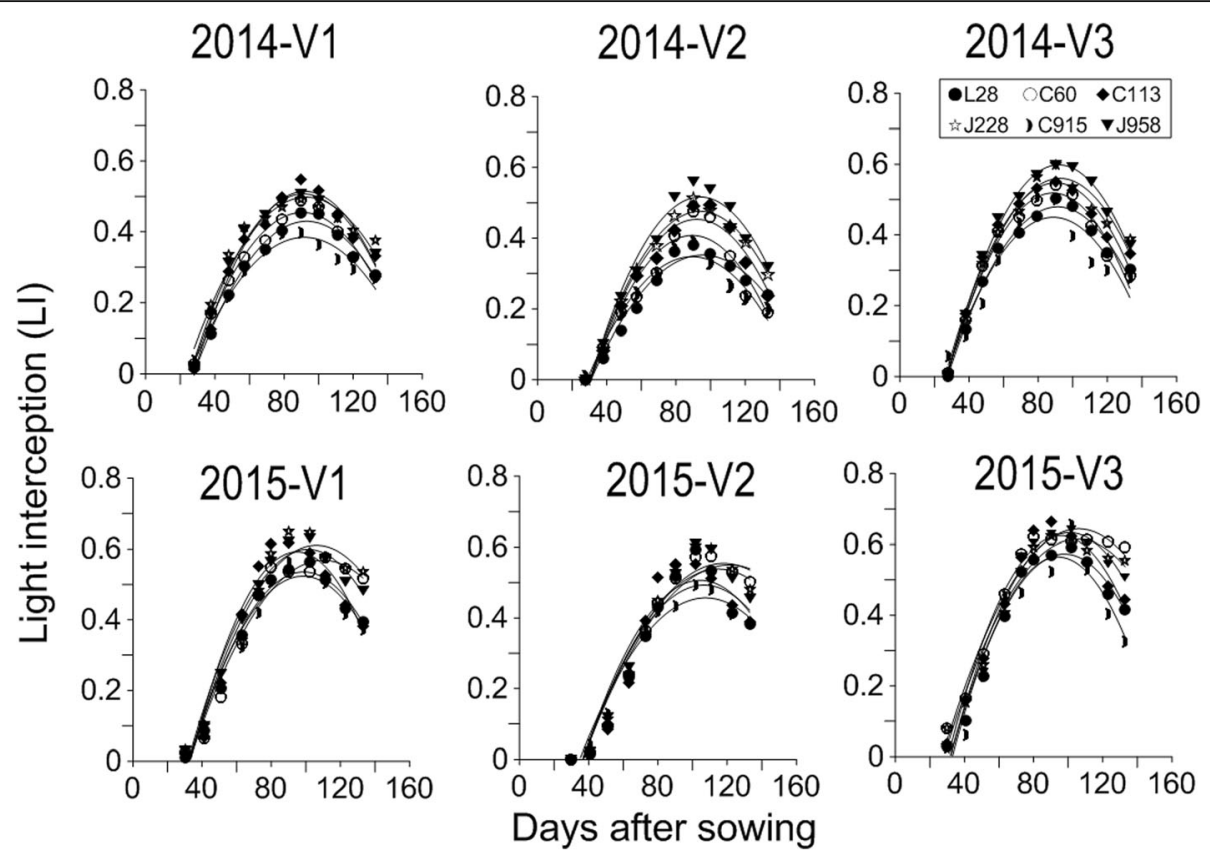

Fig. $4 \mathrm{LI}$ horizontal distribution of six different cotton varieties with different plant types during the cotton growth period in 2014 and 2015

high proportion of those assimilates efficiently into economically important organs. The total biomass differed between cotton varieties and plant types. Loose-type cotton cultivars had greater biomass than did compact-type cotton cultivars. J958 achieved the highest total biomass of $13936 \mathrm{~kg} \cdot \mathrm{hm}^{-2}$ and C915 achieved the lowest total biomass of $11879 \mathrm{~kg} \cdot \mathrm{hm}^{-2}$. $J 958$ also had a higher total biomass (13 $489 \mathrm{~kg} \cdot \mathrm{hm}^{-2}$ ) in 2015, but this was not significantly different from those of J228 and L28. C60 had the lowest total biomass in 2015. Harvest index was significantly different among cotton cultivars and plant types: compact-type cotton cultivars had a higher harvest index than did the loose-type cotton cultivars in both years (Table 3).

\section{Relationship between LI and yield formation in different cultivars}

Biomass accumulation was linearly related to the LI in both years, with $R^{2}$ values of 0.97 and 0.98 in 2014 and 2015 , respectively, although there was no significant relationship between seed cotton yield and LI (Fig. 6). The biomass of vegetative organs increased with LI and then decreased, while the biomass of reproductive organs continuously increased with LI (Fig. 7).

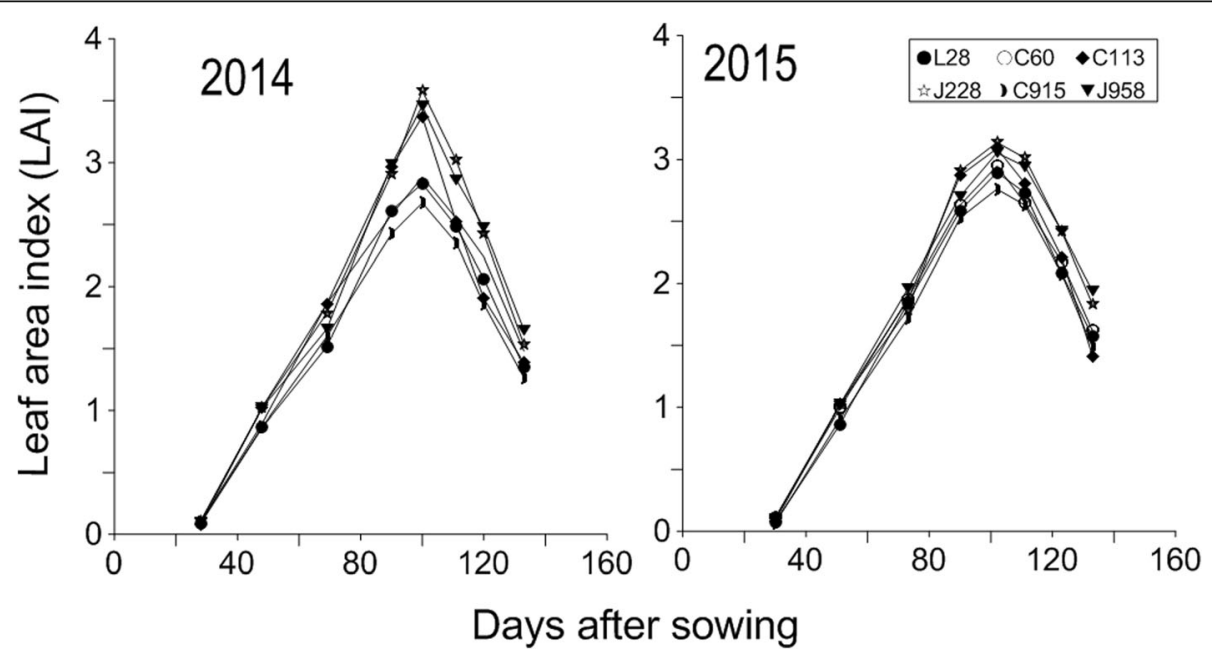

Fig. 5 Leaf area index (LAl) of six cotton varieties with different plant types during the cotton growth period in 2014 and 2015 
Table 3 Effect of cotton cultivar on cotton biomass accumulation and biomass partitioning in 2014 and 2015

\begin{tabular}{|c|c|c|c|c|c|c|c|c|c|c|c|c|c|c|c|c|}
\hline \multirow{3}{*}{$\begin{array}{l}\text { Cultivar } \\
\text { J958 }\end{array}$} & \multicolumn{4}{|c|}{$\begin{array}{l}\text { Total biomass } \\
/\left(\mathrm{kg} \cdot \mathrm{hm}^{-2}\right)\end{array}$} & \multicolumn{4}{|c|}{$\begin{array}{l}\text { Vegetative biomass } \\
/\left(\mathrm{kg} \cdot \mathrm{hm}^{-2}\right)\end{array}$} & \multicolumn{4}{|c|}{$\begin{array}{l}\text { Reproductive biomass } \\
/\left(\mathrm{kg} \cdot \mathrm{hm}^{-2}\right)\end{array}$} & \multicolumn{4}{|c|}{$\begin{array}{l}\text { Harvest index } \\
/ \%\end{array}$} \\
\hline & \multicolumn{2}{|l|}{2014} & \multicolumn{2}{|l|}{2015} & \multicolumn{2}{|l|}{2014} & \multicolumn{2}{|l|}{2015} & \multicolumn{2}{|l|}{2014} & \multicolumn{2}{|l|}{2015} & \multicolumn{2}{|l|}{2014} & \multicolumn{2}{|l|}{2015} \\
\hline & 13936 & $\mathrm{a} \S$ & 13489 & $a$ & 7800 & $a$ & 7333 & $A$ & 6137 & $b$ & 6155 & $\mathrm{~cd}$ & 44.0 & $d$ & 45.6 & c \\
\hline$J 228$ & 13429 & $a b$ & 13366 & $a$ & 6544 & $b$ & 6710 & B & 6885 & a & 6656 & $a b$ & 51.3 & $b$ & 49.8 & $b$ \\
\hline C113 & 13097 & $b c$ & 12606 & $b c$ & 6222 & $b c$ & 6265 & C & 6875 & a & 6341 & $b$ & 52.5 & $a b$ & 50.3 & b \\
\hline C60 & 12457 & c & 12416 & $b c$ & 6428 & $b$ & 6602 & $\mathrm{BC}$ & 6029 & $b$ & 5815 & $d$ & 48.4 & c & 46.8 & c \\
\hline L28 & 12867 & c & 12952 & $a b$ & 5874 & $\mathrm{~cd}$ & 6159 & $\mathrm{Cd}$ & 6993 & a & 6793 & a & 54.3 & a & 52.4 & $a$ \\
\hline C915 & 11879 & $d$ & 12181 & c & 5582 & $d$ & 5726 & $D$ & 6297 & $b$ & 6455 & $a b c$ & 53.0 & $a b$ & 53.0 & $a$ \\
\hline LSD & 769 & & 698 & & 436 & & 471 & & 352 & & 386 & & 2.1 & & 1.8 & \\
\hline
\end{tabular}

$\S$ similar lower case letters indicate no significant difference among cotton varieties at the $P=0.05$ level

Using the method that we used to analyze yield distribution, LI distribution within canopy was also calculated (data not shown). Based on regression analysis, a significant linear relationship was found between vertical cotton yield distribution and LI distribution $\left(R^{2}=0.74\right.$ in 2014 and $R^{2}=0.69$ in 2015), indicating that yield distribution within canopy is related to LI distribution. However, no significant relationship was observed between horizontal yield distribution and LI distribution, due to different plant types resulting in different zones for the inner and outer parts of the plant (Fig. 8).

\section{Discussion}

\section{Cotton yield and yield distribution of different cultivars and plant types}

Cotton yield was significantly affected by cotton cultivar (Girma et al. 2007). In this study, the cotton yields of six different cultivars ranged from 4164 to $4672 \mathrm{~kg} \cdot \mathrm{hm}^{-2}$ and 4129 to $4616 \mathrm{~kg} \cdot \mathrm{hm}^{-2}$ in 2014 and 2015, respectively. The optimal cotton yield was achieved by J958 and L28 in 2014 and by J228 in 2015, indicating the different performance of cotton cultivars in different environments. Yield was found to be a function of both boll number and boll weight, with the relative effects of each influenced by cultivar (Wang et al. 2009). In this study, J228 and J958 attained a higher cotton yield mainly due to the greater average boll weight, while L28 did so mainly due to a greater boll number per plant. Cotton yield varied significantly within plants (Bednarz et al. 2000), and yield difference can be traced to different positions within a cotton plant (Bednarz et al. 2006). Cotton boll distribution is very cultivar-dependent (Snowden et al. 2013). Our study showed that both vertical and horizontal yield distribution were affected by cotton variety and plant type. In general, loose-type cultivars had more bolls in the middle of the canopy, while compact-type cultivars had more bolls at the top and bottom of the plant, suggesting that compact-type
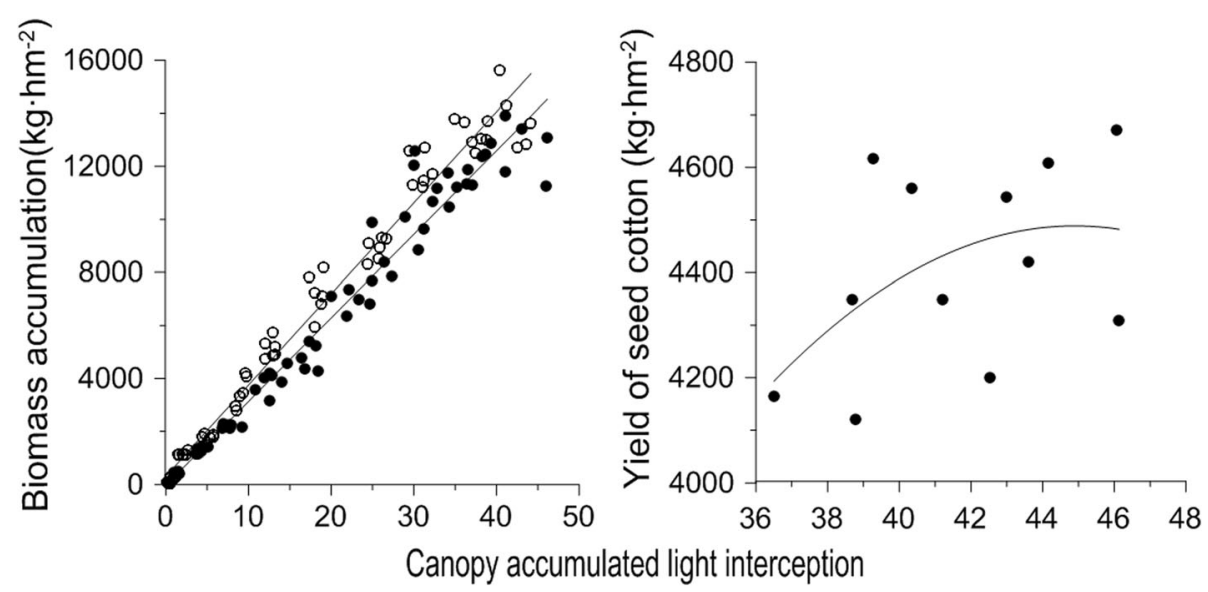

2014 Equation $Y=315.25 * X \cdot 18.17 R^{2}=0.97$

Equation $Y=-3966.90+376.69^{*} X-4.19^{*} X^{2} R^{2}=0.23$

\section{Equation $Y=343.00^{*} X+320.05 R^{2}=0.98$}

Fig. 6 Relationships of LI with biomass and yield for six cotton varieties with different plant types in 2014 and 2015 


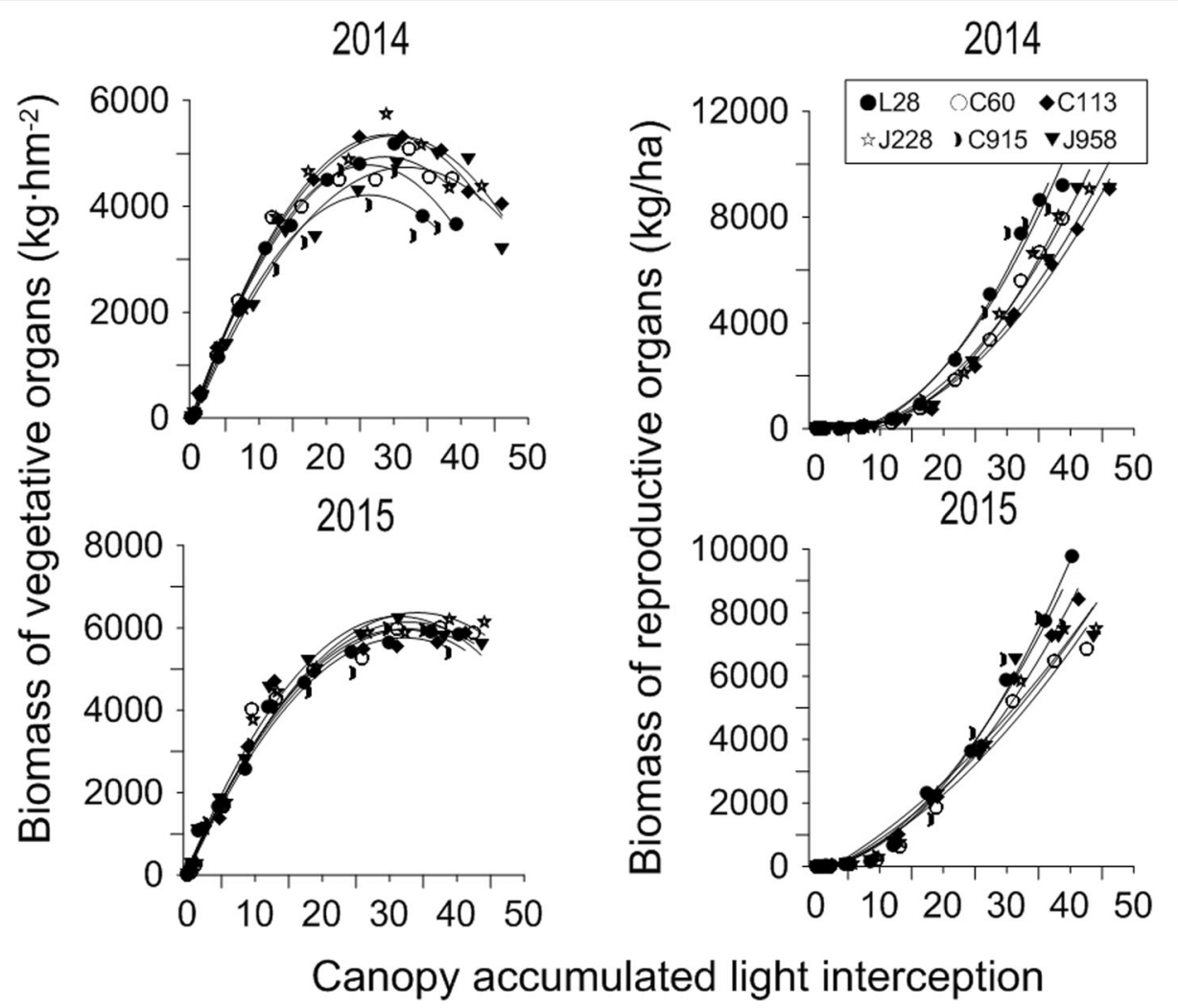

Fig. 7 Relationships of LI with vegetative biomass and reproductive biomass for six cotton varieties with different plant types in 2014 and 2015

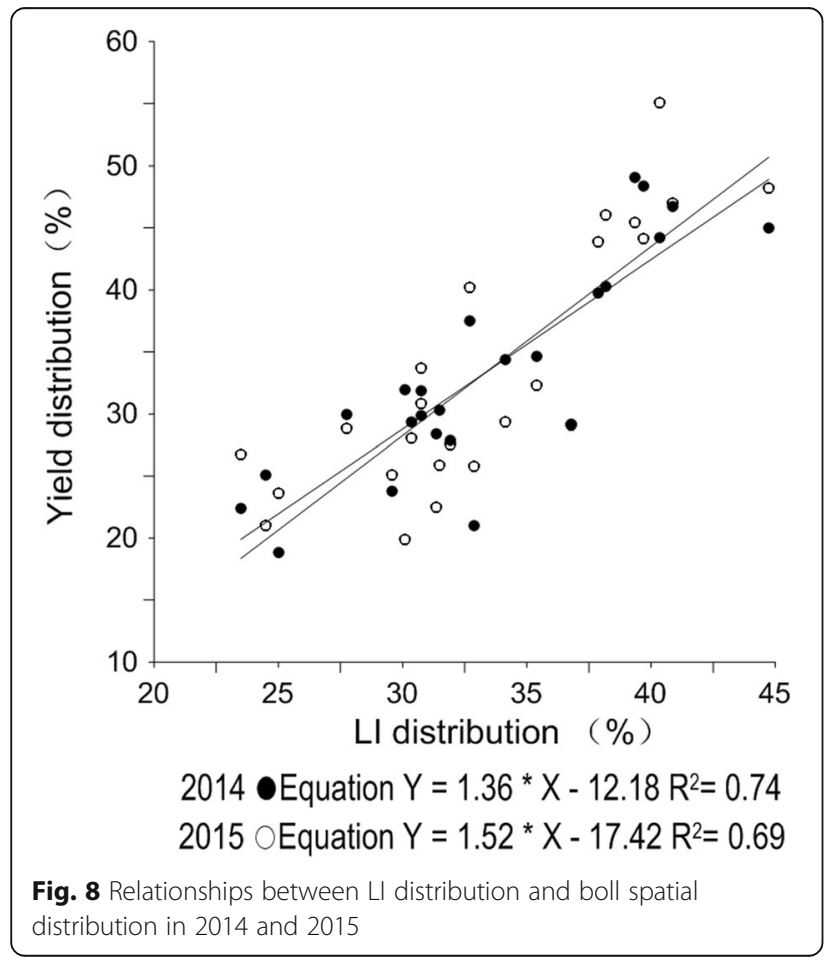

varieties distributed yield more than did loose-type varieties. Cotton bolls located in the middle canopy weighed more than those in the lower and upper canopy (CRI 2013). Therefore, a higher boll distribution in the middle canopy might be another reason for the greater boll weight of loose-type cotton varieties (J958 and J228), in addition to genetic difference. Cotton varieties with a compact plant type showed relatively more yield distribution in the inner part of the plant only in 2014, but this did not occur in 2015. During the cotton growth period, with more rainfall in 2014, fruiting branches grew faster, especially in loose-type varieties, resulting in relatively greater outer yield distribution for loose-type than for compact-type cotton varieties.

\section{Canopy $\mathrm{LI}$ and $\mathrm{LI}$ distribution of different varieties and plant types}

As the primary source of energy, light plays an important role in plant growth. LI by the canopy is an important factor determining biomass production and crop development (Chenu et al. 2005; Escobar-Gutiérrez et al. 2009). The interception of light by the crop canopy is complicated and is affected by the canopy architecture (Mariscal et al. 2000). The canopy structure of a crop is determined largely by the plant type. In this study, the loose-type cultivars intercepted more LI than did 
compact-type cultivars in both years, mainly due to the greater LI in full-flowering and boll-setting stages. The peak LI occurred later in 2015 relative to 2014 due to the lower temperature and less rainfall in 2015 resulting in slow plant growth and development. The greater LI of loose-type cotton varieties could be explained by higher peak LAI, which was a determinant factor of LI by the cotton canopy (Reynolds et al. 2000). Plant type can also affect canopy light distribution(Arduini et al. 2006). LI distribution within canopy was significantly different among cotton cultivars and plant types both vertically and horizontally. The loose-type cultivars intercepted more light than did the compact-type cultivars in $\mathrm{H} 2$, $\mathrm{H} 3$ and V2 in both years, indicating that the difference in LI of the whole canopy among different cotton cultivars mainly resulted from the LI of the middle and upper canopy and of the outer canopy. Due to the longer fruiting branches and higher LAI of loose-type cotton cultivars, the light transmittance to the lower canopy is relatively less compared with that to the upper and middle canopy.

\section{The relationship between yield and $\mathrm{LI}$ in different cultivars and plant types}

Optimum canopy structure is the basis of improving photosynthetic efficiency and achieving high crop yields(Da Silva et al. 2014; Zhang et al. 2008). In this study, a significant linear relationship was observed between total biomass accumulation and accumulated LI, which was consistent with previous studies (Xue et al. 2015; Zarate-Valdez et al. 2012; Monteith 1977). However, no obvious relationship was observed between cotton yield and the total canopy-accumulated LI, which was also found by Zarate-Valdez et al. (2012) and Xue et al. (2015). A possible explanation for this result might be the different transport efficiency of LI to reproductive organs as indicated by different harvest index values. However, for each cultivar, cotton reproductive organs biomass was positively related to LI, indicating that increasing LI can effectively improve cotton yield for each cultivar. In addition, there was a linear relationship between vertical cotton yield distribution and LI distribution within the canopy, indicating that yield distribution within the canopy is in accordance with LI distribution. Therefore, proper canopy architecture can optimize yield distribution and subsequently improve cotton yield and fiber quality by optimizing LI distribution.

\section{Methods}

\section{Experimental design}

The field experiment was conducted in 2014 and 2015 at the experimental farm of the Cotton Research Institute of the Chinese Academy of Agricultural Sciences in Anyang, Henan, China ( $\left.36^{\circ} 06^{~} \mathrm{~N}, 114^{\circ} 21^{\prime} \mathrm{E}\right)$. The field design was a randomized complete block with six different selected cotton cultivars belonged to 3 different plant types. J958 and J228 had a loose plant type and tended to have horizontally fruiting branches. C60 and C113 had a medium plant type with shorter branches and leaves of medium size. L28 and C915 had a compact plant type with short fruiting branches and close-set fruiting nodes. The experimental design was replicated three times with a plot size of $8 \times 8 \mathrm{~m}$ and the row orientation was north to south. The sowing dates were April 30, 2014 and April 24, 2015, respectively, and manually thinned out to a desired density of 60000 plants $\cdot \mathrm{hm}^{-2}$ at the two-leaf stage. The weather conditions for the area are provided in Table 4.

In both years, the land was plowed and irrigated in early spring before planting. The cotton was fertilized with $225 \mathrm{~kg} \cdot \mathrm{hm}^{-2} \mathrm{~N}, 150 \mathrm{~kg} \cdot \mathrm{hm}^{-2} \mathrm{P}_{2} \mathrm{O}_{5}$ and $225 \mathrm{~kg} \cdot \mathrm{hm}^{-2} \mathrm{~K}_{2} \mathrm{O}$ before sowing. Supplemental irrigation was provided at a total volume of approximately $45 \mathrm{~mm}$ by flooding the furrows during the flowering stage. Other field management activities were conducted according to local agronomic practices.

\section{Data collection \\ PAR interception and transmission in the canopy}

We measured transmission PAR (TPAR) and reflection PAR (RPAR) in different canopy layers every ten days using a portable $1.0 \mathrm{~m}$ light quantum sensor (LI-191SA, LI-COR, Lincoln, NE,USA) and a data logger (LI-1400, LI-COR, Lincoln, NE, USA). The measurement by the spatial grid sampled method in the same sample area of each plot during the crop season between the square stage and maturity in each year and were performed $1 \mathrm{~h}$ before solar noon under clear skies. The sample row was divided 5 measuring position between two rows in the horizontal distance. Similarly, in the vertical direction, we divide canopy into layers of every $20 \mathrm{~cm}$. In addition, the incident PAR (IPAR) above the canopy was automatically monitored and recorded at every $5 \mathrm{~s}$ intervals.

Table 4 Weather information for the cotton growth season in 2014 and 2015

\begin{tabular}{|c|c|c|c|c|c|c|}
\hline \multirow[t]{2}{*}{ Month } & \multicolumn{2}{|c|}{$\begin{array}{l}\text { Accumulated } \\
\text { temperature } \geq 10{ }^{\circ} \mathrm{C} /{ }^{\circ} \mathrm{C}\end{array}$} & \multicolumn{2}{|c|}{ Precipitation /mm } & \multicolumn{2}{|c|}{ Sunshine time /h } \\
\hline & 2014 & 2015 & 2014 & 2015 & 2014 & 2015 \\
\hline 4 & 487.7 & 359.9 & 79.6 & 31.1 & 145.1 & 224.4 \\
\hline 5 & 737.3 & 642.1 & 33.8 & 59.7 & 220.5 & 239.9 \\
\hline 6 & 769.8 & 781.7 & 116.7 & 19.9 & 163.6 & 193.6 \\
\hline 7 & 828.7 & 837.8 & 130.9 & 72.4 & 168.6 & 221.2 \\
\hline 8 & 761.8 & 801.5 & 65.7 & 29.0 & 160.9 & 193.8 \\
\hline 9 & 612.1 & 633.9 & 193.5 & 17.2 & 87.7 & 176.9 \\
\hline 10 & 515.7 & 458.4 & 4.8 & 18.2 & 97.5 & 176.2 \\
\hline
\end{tabular}


The TR (transmitted PAR rate), RR (reflected PAR rate),IR (intercepted PAR rate) were calculated using the following equations (Zhi et al. 2014):

$$
\begin{aligned}
& T R=T P A R / I P A R \\
& R R=R P A R / I P A R \\
& I R=1-T R-R R
\end{aligned}
$$

\section{Estimation of PAR distribution in the canopy}

In other positions within the canopy, IR and TR values were calculated by spatial interpolation using the following equation:

$$
Z\left(X_{0}\right)=\sum_{\mathrm{i}=1}^{\mathrm{n}} \lambda_{i} Z\left(X_{i}\right)
$$

where $\mathrm{Z}\left(\mathrm{X}_{0}\right)$ is the measured PAR value; $\lambda_{\mathrm{i}}$ is the coefficient of the sample, and unbiased condition $=1$ was employed.

Furthermore, based on the minimum variance, the Kriging equation was stated as follows:

$$
\sum_{i=1}^{\mathrm{n}} \lambda_{i} r\left(x_{i}, x_{j}\right)+\phi=r\left(x_{i}, x_{0}\right)
$$

where $r\left(x_{i}, x_{j}\right)$ is the measured value of the variation function; $\phi$ is the Lagrangian, $r\left(x_{i}, x_{0}\right)$ is the measured and calculated PAR, and $x_{0}$ is the estimated value of the calculated point as computed by the unbiased estimate.

\section{Calculation of accumulated TR within the whole canopy}

The following trapezoidal rules based on the Surfer software V11 (Golden Software Inc., USA) was used to calculate accumulated TR within the whole canopy.

$$
\begin{aligned}
& S_{i}=\Delta x / 2\left[h_{(i, 1)}+2 h_{(i, 2)}+2 h_{(i, 3)}+\ldots . .+2 h_{(i, n-1)}+h_{(i, n)}\right] \\
& \text { Volume }=\Delta y / 2\left[s_{1}+2 s_{2}+2 s_{3}+\ldots . .2 s_{n-1}+s_{n}\right]
\end{aligned}
$$

where the coefficient vector is $[1,2,2,2, \ldots, 2,2,2,1]$; $\Delta \mathrm{x}$ is the vertical distance of the grid, $\Delta \mathrm{y}$ is the horizontal distance; $h(i, j)$ is the grid node value in row $\mathrm{i}$ and column $\mathrm{j}$.

\section{Determination of the agronomic traits of cotton}

Three plants were randomly uprooted from the center of each test plot and then divided into roots, stems, leaves and reproductive organs. For each plot, ten plants were randomly sampled for plant mapping to count boll numbers. The leaf area was determined using a scanner (Phantom 9800xl; Microtek, Shanghai, China) and Image-Pro plus 7.0 (Media Cybernetics, Rockville, MD, USA). The dry matter of the cotton plants was determined by drying at $80{ }^{\circ} \mathrm{C}$ to a constant weight. Cotton seed yield was manually harvested three times in 2014 and 2015, respectively.

\section{Yield and yield component determination}

In the beginning of October, cotton bolls from an area of $8 \mathrm{~m}^{2}(0.8 \mathrm{~m} \times 10 \mathrm{~m})$ in the central two rows of each plot were hand-harvested for cotton yield estimation. Plant density, boll number per plant and average seed cotton weight per boll were recorded to calculate the cotton yield.

\section{Determination of spatial yield distribution}

Before harvest, final plant mapping measurements were made on 30 consecutive undamaged plants in the two middle rows of each plot. Measurements included plant height, total nodes, and bolls present by fruiting site on each individual plant. Bolls located from the first to the fourth fruiting branches were designated as the lower bolls, those in the fifth to the eighth fruiting branches were middle bolls and those in the ninth and higher fruiting branches were upper bolls. In addition, bolls in the first and second fruit positions were referred to as inner bolls and those in the third fruit position and beyond were outer bolls. Yield spatial distribution was then determined by the boll number in each fruiting site divided by the total number of bolls per plant.

\section{Statistical analysis}

The experimental data were analyzed with SPSS 11.0. Differences between treatment means were tested for significance using least significant difference (LSD) after analysis of variance, which indicated a significant treatment effect by $F$-test at the probability level of 0.05 .

\section{Conclusions}

This study demonstrated the effects of cotton cultivar and plant type on cotton yield, yield distribution, LI, LI distribution, and the relationship between yield and LI. In this study, loose-type cotton cultivars intercepted more accumulated LI than did compact-type cotton cultivars due to there being more LI in the middle and upper canopy. Although loose-type varieties had greater LI, they did not have distinct advantages in cotton yield comparing with compact-type cultivars, no significant relationship was observed between cotton yield, and canopy-accumulated LI resulted from different harvest index values of different cotton cultivars, therefore, for loose-type cotton cultivars with high LI in this study, improving the harvest index by adjusting the source-to-sink relationship is a way to further increase cotton yield. In addition, there was a positive relationship between reproductive organ biomass accumulation and canopy-accumulated LI, indicating that enhancing LI is important for yield improvement for each cultivar. 
Furthermore, the yield distribution within canopy was significantly linearly related to vertical LI distribution. Therefore, optimizing the canopy structure and subsequently optimizing the LI distribution within the cotton canopy can effectively manipulate the yield distribution, which can further influence cotton yield and fiber quality.

\section{Acknowledgements}

The authors are grateful for the work of the technicians at the experimental station of the Institute of Cotton Research of Chinese Academy of Agricultural Sciences.

\section{Funding}

This work was funded by the National Natural Science Foundation of China (31371561)

\section{Availability of data and materials}

The datasets used and analyzed during the current study are available from the corresponding author on reasonable request.

\section{Authors' contributions}

$L i Y B$, Han YC, Wang GP designed the study. Xing FF, Feng L and Zhi XY wrote the main manuscript text and prepared figures 1-8. Xiong SW, Wang ZB, Fan ZY, Du WL carried out the experimental work and Yang BF, Xing FF, Lei YP, Feng L, Zhi XY analyzed data. All authors reviewed the manuscript. All authors read and approved the final manuscript.

\section{Ethics approval and consent to participate}

Not applicable.

\section{Consent for publication}

Not applicable.

\section{Competing interests}

The authors declare that they have no competing interests.

Received: 24 May 2018 Accepted: 21 September 2018

\section{Published online: 07 November 2018}

\section{References}

Arduini I, Masoni A, Ercoli L, Mariotti M. Grain yield, and dry matter and nitrogen accumulation and remobilization in durum wheat as affected by variety and seeding rate. Eur J Agron. 2006;25:309-18. https://doi.org/10.1016/j.ja.2006. 06.009.

Bai ZG, Mao SC, Han YC, et al. Study on light interception and biomass production of different cotton cultivars. PLoS One. 2016;11(5):e0156335. https://doi.org/10.1371/journal.pone.0156335.

Baldissera TC, Frak E, Carvalho PCD, Louarn G. Plant development controls leaf area expansion in alfalfa plants competing for light. Ann Bot. 2014;113:14557. https://doi.org/10.1093/aob/mct251.

Barthélémy D, Caraglio Y. Plant architecture: a dynamic, multilevel and comprehensive approach to plant form, structure and ontogeny. Ann Bot. 2007;99:375-407. https://doi.org/10.1093/aob/mcl260.

Bednarz CW, Bridges DC, Brown SM. Analysis of cotton yield stability across population densities. Agron J. 2000;92:128-35. https://doi.org/10.2134/ agronj2000.921128x.

Bednarz CW, Nichols RL, Brown SM. Plant density modifications of cotton withinboll yield components. Crop Sci. 2006;46(5):2076-80. https://doi.org/10.2135/ cropsci2005.12.0493.

Chen JM, Blanken PD, Black TA, et al. Radiation regime and canopy architecture in a boreal aspen forest. Agric For Meteorol. 1997;86:107-25. https://doi.org/ 10.1016/S0168-1923(96)02402-1.

Chenu K, Franck N, Dauzat J, et al. Integrated responses of rosette organogenesis, morphogenesis and architecture to reduced incident light in Arabidopsis thaliana results in higher efficiency of light interception. Functional Plant Biol. 2005;32:1123-34. https://doi.org/10.1071/FP05091.

CRI (Cotton Research Institute, Chinese Academy of Agricultural Sciences). Cultivation of cotton in China. Shanghai: Shanghai Science and Technology Press; 2013. (in Chinese).
Da Silva D, Han L, Costes E. Light interception efficiency of apple trees: a multiscale computational study based on MAppleT. Ecol Model. 2014;290:4553. https://doi.org/10.1016/j.ecolmodel.2013.12.001.

Dauzat J, Clouvel P. Luquet D, Martin P. Using virtual plants to analyse the lightforaging efficiency of a low-density cotton crop. Ann Bot. 2008;101:1153-66. https://doi.org/10.1093/aob/mcm316.

Escobar-Gutiérrez A, Combes $\mathrm{D}$, Rakocevic $\mathrm{M}$, et al. Functional relationships to estimate morphogenetically active radiation (MAR) from PAR and solar broadband irradiance measurements: the case of a sorghum crop. Agric Meteorologica. 2009;149:1244-53.https://doi.org/10.1016/j.agrformet.2009.02.011.

Girma K, Teal RK, Freeman KW, et al. Cotton lint yield and quality as affected by applications of N, P, and K fertilizers. J Cotton Sci. 2007;11:12-9.

Kaggwa-Asiimwe R, Andrade-Sanchez P, Wang GY. Plant architecture influences growth and yield response of upland cotton to population density. Field Crops Res. 2013;145:52-9. https://doi.org/10.1016/j.fcr.2013.02.005.

Louarn G, Lecoeur J, Lebon E. A three-dimensional statistical reconstruction model of grapevine (Vitis vinifera) simulating canopy structure variability within and between cultivar/training system pairs. Ann Bot. 2008;101:116784. https://doi.org/10.1093/aob/mcm170.

Madakadze IC, Stewart K, Peterson PR, et al. Light interception, use-efficiency and energy yield of switchgrass (Panicum virgatum L.) grown in a short season area. Biomass Bioenergy. 1998;15:475-82. https://doi.org/10.1016/50961-9534(98)00060-9.

Maddonni GA, Otegui ME. Leaf area, light interception, and crop development in maize. Field Crops Res. 1996;48:81-7. https://doi.org/10.1016/03784290(96)00035-4.

Mariscal M, Martens S, Ustin S, et al. Modelling and measurement of radiation interception by olive canopies. Agric For Meteorol. 2000;100:183-97. https:// doi.org/10.1016/S0168-1923(99)00137-9.

Mclntyre BD, Riha SJ, Ong CK. Light interception and evapotranspiration in hedgerow agroforestry systems. Agric For Meteorol. 1996;81:31-40. https:// doi.org/10.1016/0168-1923(95)02303-8.

Meir P, Kruijt B, Broadmeadow M, et al. Acclimation of photosynthetic capacity to irradiance in tree canopies in relation to leaf nitrogen concentration and leaf mass per unit area. Plant Cell Environ. 2002;25:343-57. https://doi.org/10. 1046/j.0016-8025.2001.00811.x.

Mo XG, Liu SX, Lin ZH, et al. Prediction of crop yield, water consumption and water use efficiency with a SVAT-crop growth model using remotely sensed data on the North China plain. Ecol Model. 2005;183:301-22. https://doi.org/ 10.1016/j.ecolmodel.2004.07.032.

Monteith JL. Climate and the efficiency of crop production in Britain. Philos Trans R Soc Lond B Biol Sci. 1977;281:277-94. https://doi.org/10.1098/rstb. 1977.0140

Reynolds MP, Delgado Ml, Gutiérrez-Rodríguez M, Larqué-Saavedra A. Photosynthesis of wheat in a warm, irrigated environment: I: Genetic diversity and crop productivity. Field Crops Res. 2000;66:37-50. https://doi. org/10.1016/S0378-4290(99)00077-5.

Snowden C, Ritchie GL, Cave J, et al. Multiple irrigation levels affect boll distribution, yield, and fiber micronaire in cotton. Agron J. 2013;105:1536-44. https://doi.org/10.2134/agronj2013.0084.

Vargas LA, Andersen MN, Jensen CR, Jørgensen U. Estimation of leaf area index, light interception and biomass accumulation of Miscanthus sinensis 'Goliath' from radiation measurements. Biomass Bioenergy. 2002;22:1-14.

Wang Q, Han S, Zhang LZ, et al. Boll size affects the insecticidal protein content in Bacillus thuringiensis (Bt) cotton. Field Crops Res. 2009;1 10:106-10. https:// doi.org/10.1016/j.fcr.2008.07.008.

Wang Q, Han S, Zhang LZ, et al. Density responses and spatial distribution of cotton yield and yield components in jujube (Zizyphus jujube)/cotton (Gossypium hirsutum) agroforestry. Eur J Agron. 2016;79:58-65. https://doi. org/10.1016/j.eja.2016.05.009.

Xue HY, Han YC, Li YB, et al. Spatial distribution of light interception by different plant population densities and its relationship with yield. Field Crops Res. 2015;184:17-27. https://doi.org/10.1016/j.fcr.2015.09.004.

Zarate-Valdez $\mathrm{LL}$, Whiting ML, Lampinen BD, et al. Prediction of leaf area index in almonds by vegetation indexes. Comput Electron Agr. 2012;85:24-32. https:// doi.org/10.1016/j.compag.2012.03.009.

Zhang L, Van der Werf W, Bastiaans L, et al. Light interception and utilization in relay intercrops of wheat and cotton. Field Crops Res. 2008;107:29-42. https://doi.org/10.1016/j.fcr.2007.12.014.

Zhi XY, Han YC, Mao SC, et al. Light spatial distribution in the canopy and crop development in cotton. PLoS One. 2014;9:1-10. https://doi.org/10.1371/ journal.pone.0113409. 